J. Perinat. Med. 4 (1976) 100

\section{The significance of the time interval in twin delivery}

Wolfgang Müller-Holve, Erich Saling, Martin Schwarz

Unit of Perinatal Medicine - The Free University of Berlin

Department of Obstetrics and Gynecology, Berlin-Neukölln
In addition to other clinical questions of twin pregnancies and twin deliveries, a number of authors have dealt with the influence of the time interval in twin births upon the fate of the second twin [1-10 and 12-14]. Most authors concluded that a very brief interval is unfavorable for the second twin. From this a favorable "time zone" has been promoted during which the risk of the second twin is said to be at a minimum $[1,5,13]$. Only after exceeding this time zone, which has been given variously as between 10 minutes $[5,13]$ and 60 minutes [1] is an increased risk for the second twin assumed.

\section{Our points of view}

A closer review of the criteria which have led to these statements suggests further and more detailed analysis:

1. The principal criterion has usually been the mortality of the second twin in comparison to that of the first twin. Indications for morbidity by assessing the status of the infant immediately post partum with the clinical and the acidity scores are of far greater relevance.

2. The various methods of delivery usually have not been taken into account. Thus it is easily seen that second twins delivered at shorter intervals because of a Caesarean section appear to have a higher mortality if the section was done for a fetal indication.

\section{Curriculum vitae}

Wolfg. MƯLLER-HOLVE, born in 1940. Studies of Medicine at the Universities of Tübingen and Innsbruck 1960-1965. State examination and MD graduation 1966. Rotating internship in Germany and France 1966-1968. Department of Obstetrics and Gynecology at the Ev. Krankenhaus Köln 19681970. Training in perinatal intensive care at the Unit of Perinatal Medicine of the Free University of Berlin

1969. Hospital Andino Peru South America 1971. Training in Anesthesiology at the Institute of Anesthesiology of the University of Freiburg 1972. Since December 1972 Department of Obstetrics and Gynecology, Berlin-Neukölln. In 1974 Diploma as a specialist in Obstetrics and Gynecology and since then Unit of Perinatal Medicine of the Free University of Berlin within the Department of Obstetrics and Gynecology, Berlin-Neukölln.

3. The twins have usually not been separated into various weight classes. For a very low birth weight, high-risk second twin, this may result in a shorter time interval because of the lesser resistance in the birth canal.

4. Lastly, the positional anomalies found more frequently in second twins $[6,9]$ lead to an increased risk for the second twin.

This lack of criteria in the investigations to date on the influence of the delivery interval.on the second 
twin caused us to analyze a more comparable group of twins, in whom clinical and biochemical observations had been made.

\section{Materials and Methods}

Since we introduced the routine determination of the $\mathrm{pH}$ in the umbilical arterial blood of infants, i.e. from July 1, 1970 through December 31,1974 , there were 84 twin deliveries in our hospital. Among these there were 35 twin deliveries which fulfilled the following criteria for inclusion in the study:

1. Both twins were born from a vertex presentation.

2 . Both twins were delivered vaginally.

3. Both twins had birth weights over $2000 \mathrm{~g}$.

The following parameters were analyzed as to the influence of the time interval:

1. The clinical state of the second twin according to our main scoring system [11].

2. The difference of the clinical status between the two twins.

3. The separate factors of our subsidiary score, e.g. first breath, first cry, etc. [11].

4. The umbilical artery $\mathrm{pH}$ value of the second twin.

5. The difference of the umbilical artery $\mathrm{pH}$ between the two twins.

6. The difference between the pHact. and the pHqu40 values of the second twin.

During the observation period, the clinical management following the birth of the first twin was uniform: because there was usually no evaluable cardiotocogram of the second twin available, the heart beats of the second twin were monitored with an ultrasound puls detector. If there were suspicious patterns of cardiac frequency (persistent bradycardia or severe decelerations), the second amniotic membrane, if intact, was ruptured. In those cases in which the head did not rapidly descend into the pelvis, a vacuum extraction was performed. If the head did descend quickly, we aimed for a spontaneous delivery by augmenting contractions with oxytocin and by occasionally using KRISTELleR's maneuver. If however the heart rate of the second twin was normal, we proceeded deliberately and ruptured the second mem- brane, if intact, after a few additional contractions. By this management, time differences of up to 25 minutes occured in this group.

\section{Results}

The clinical status of the second twins did not differ significantly from that of the first twins. The point differences in the scores of the second and first twins (main score) and the absolute score points of the main scores of the second twins were correlated with the time intervals. Neither analysis showed significant differences, although in both there was a trend for lower values for the second twins.

The objective findings of the subsidiary score, which are timed with a stopwatch as a complement of the clinical status diagnosis, showed no correlation with the time interval.

In contrast there is a good correlation between the umbilical artery pHact. values of the second twins and the time interval (Fig. 1). We found that a $\mathrm{pH}$ value of 7.15 was the value which separated best groups with a poorer against those with a better acid-base status. When we separated the groups according to brief or long time intervals between the birth of the first and the second twin, we analyzed first whether the 5-minute interval was correlated with a significant difference. While there was a noticeable tendency for a decrease, the difference was not significant. However, at a 7-minute time interval the difference became significant $(2 p<0.05)$. The separation at the 10 minute interval resulted also in a significant difference $(2 p<0.01)$.

The influence of the time interval on the metabolic acidity of the second twin was analyzed at these $\mathrm{pH}$ values and time intervals. The $\mathrm{pHqu} 40$ values of the umbilical artery blood of the second twin at the $\mathrm{pH}$ limit of 7.15 and at the 7-and 10-minute intervals show significant differences (7-minute intervall: $2 p<0.05,10$-minute interval: $2 p<0.01$ ). From the consideration that any noxious influence which is common for both twins such as an increased maternal metabolic acidity will change the $\mathrm{pH}$ values of both twins in the same direction, we examined whether the additional risk for acidosis of the second twin from the 'delivery interval 


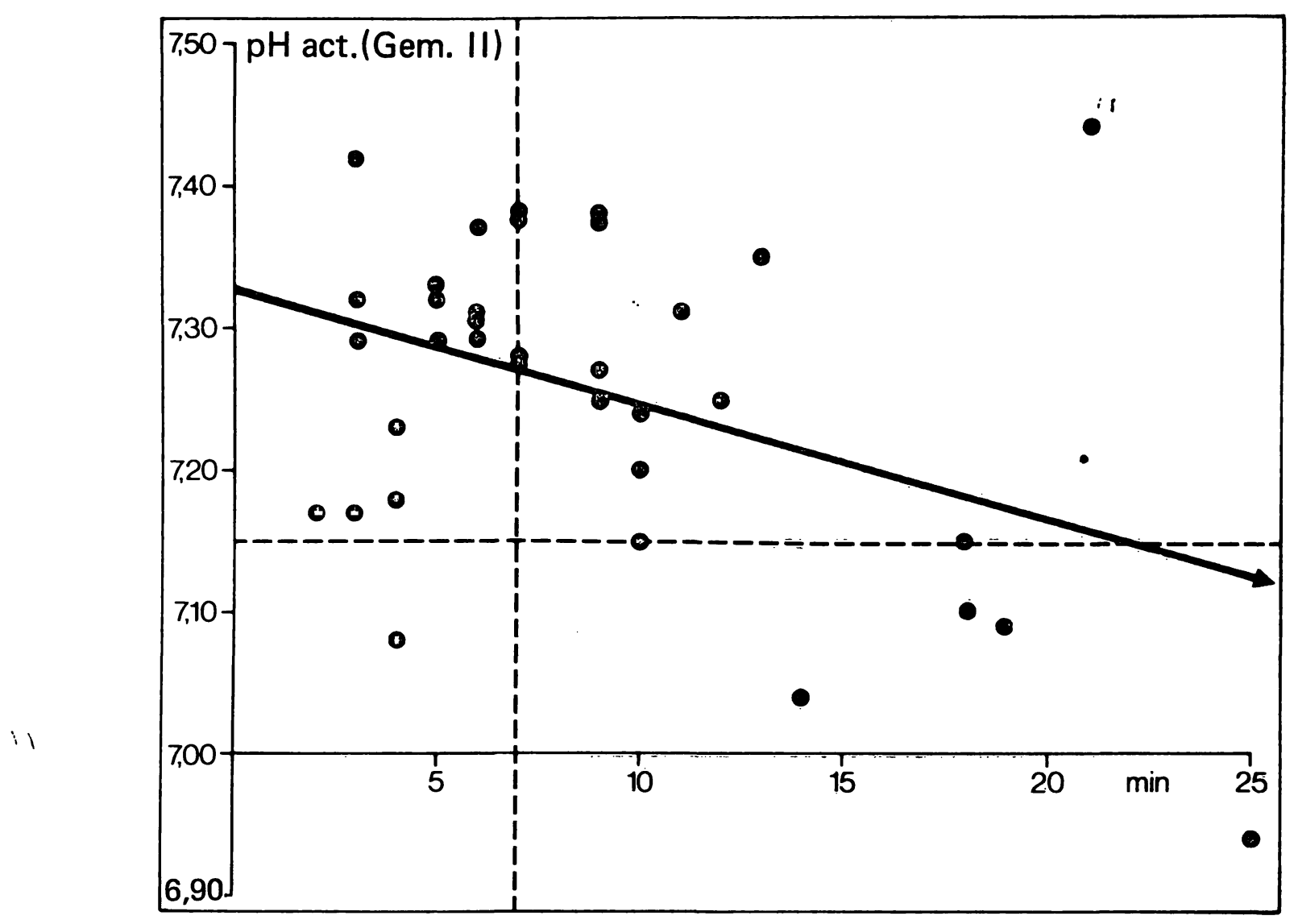

Fig. 1. Correlation of the actual $\mathrm{pH}$ values in the umbilical artery blood of the second twin to the delivery interval. Four groups are compared by establishing a 7-minute interval line and a $\mathrm{pH}$ value of 7.15 (borderline values are counted towards the left and upper group).

could be analyzed statistically. Therefore we analyzed the $\Delta$-pHact. values in the umbilical. artery blood which were obtained by subtracting the values of the second twin from that of the first twin (Fig. 2).

The zero line was established as a separator between the two groups, i.e. if the $\mathrm{pH}$ value of the first twin was above that of the second twin, a group was formed which could be separated from a group in which the $\mathrm{pH}$ value of the second twin was higher than that of the first twin. In order to apply the $\chi^{2}$ test the vertical separation was established again at $7-$ and 10-minute time intervals. Any values which fell on the separating lines were counted toward the left and lower group*. This analysis yielded the following statistically signifi-

\footnotetext{
* For to receive statistically most different groups, values on separating lines were counted once to lower (see Fig. 2) once to upper group (see Fig. 1).
}

cant result: Differences of the actual $\mathrm{pH}$ values at 7-minute intervall: $\chi^{2}=3.84, p<0.05$. Differences of the pHqu 40 values at the 10-minute intervall: $\chi^{2}=4.27, p<0.05$.

Finally we also attempted to investigate the difference of the actual $\mathrm{pH}$ and the $\mathrm{pHqu} 40$ in the umbilical artery blood of the second twin in relation to the time interval. This might have indicated an increase of more acute hypoxic disturbances in second twins, because a high difference could be interpreted as such an acute disturbance. However, there was no significant correlation.

\section{Discussion}

If the $\mathrm{pH}$ of the umbilical artery blood can be assumed to reflect fetal hypoxia, our results would suggest that, for twin deliveries, the interval between the birth of both infants should be kept as low as possible. 


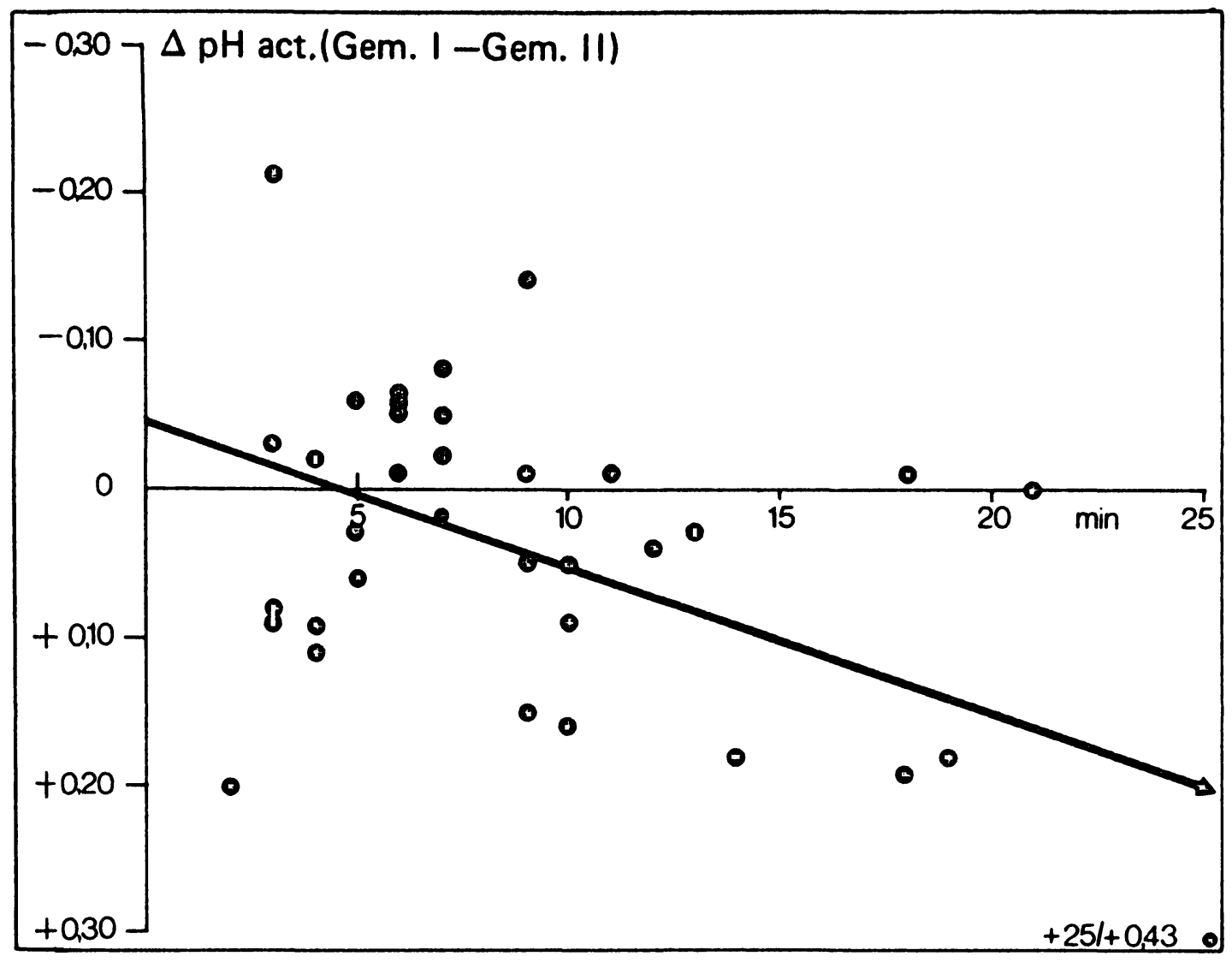

Fig. 2. Differences of the actual $\mathrm{pH}$ values in the umbilical artery blood between first and second twins in relation to the delivery interval.

The results of the clinical scoring of the second twin, however, do not allow this conclusion. This appears to be in contradiction to the fact that there are correlations between the time interval and the mortality of twins $[1,5,13]$. This apparent discrepancy, in our opinion, can be explained by the fact that between the beginning of any hypoxia and its influence on the clinical status there is always a lag period. While in a term infant a relatively brief hypoxia is usually not accompanied by much risk of distress, the situation with small and premature twins is considerably more critical. In these cases any increase in acidity or any acidosis with or without slight clinical depression must be judged much more seriously [5]. The metabolism of these infants cannot overcome disturbances in the acid-base balance as quickly as that of mature infants who are clinically little impaired. From this point of view an evaluation of the acidity state of the second twin, which constitutes a rational parameter, is of particular importance.

Clinically our results suggest that after the birth of the first twin one should not proceed with undue haste, but expeditiously, according to the clinical situation (e.g. vertex, breech or transverse position of the second twin) in order to deliver the second twin without unnecessary delay.

1. vertex presentation

2. vaginal deliveries

3. birth weight above $2000 \mathrm{~g}$.

We analyzed various parameters in the clinical and acidity score of the second twin alone as well as in comparison to 
the first twin. The following points of view were considered:

1. The more sensitive aspect of morbidity was utilized by including the assessment of the state of the newborn rather than just mortality.

2. Since Caesarean sections in twins are often performed for a fetal indication, short time intervals between the birth of both infants correlate intrinsically with a higher risk for the second twin. Therefore we considered only vaginal deliveries in order to exclude this intrinsic correlation.

3. By excluding infants below a birth weight of $2000 \mathrm{~g}$, the influence of the low birth weight of the second twin was eliminated.
4. The frequently occurring positional anomalies of the second twin will deteriorate the conditions independent of the time interval. Therefore we have considered only births from vertex presentations.

A comparison of the acidity state demonstrated that the actual $\mathrm{pH}$ values in the umbilical artery blood of these second twins (Fig. 1) decrease statistically significantly with increasing time intervals. This is also true for metabolic acidity (pHqu40). The differences of the actual $\mathrm{pH}$ values (Fig. 2) and the pHqu40 values between the first and second twin decreases significantly also with an increasing time interval.

Our results indicate that obstetricians, according to the clinical conditions, should accomplish the birth of the second twin as soon as possible after the birth of the first twin.

Keywords: Acid-base status, acidosis, clinical status, fetus, twin delivery

\section{Zusammenfassung}

Die Bedeutung des Zeitintervalls bei der Zwillingsgeburt Um den Einfluß des Zeitintervalles bei der Zwillingsgeburt auf den 2. Zwilling zu untersuchen, haben wir noch strengere Beurteilungskriterien, als sie bisher im Schrifttum angegeben wurden, zugrunde gelegt. Im Zeitraum vom 1. 7. 1970 bis 31.12 .1974 wurden $35 \mathrm{Zwillingsgeburten}$ unserer Klinik erfaßt, die folgende Bedingungen erfüllen konnten:

1. Geburt beider Zwillinge aus Schädellage.

2. Vaginale Geburt beider Zwillinge.

3. Geburtsgewicht über $2000 \mathrm{~g}$.

Untersucht wurden verschiedene Parameter im clinical and acidity score sowohl des zweiten $Z$ willings alleine als auch im Vergleich $z$ wischen beiden Zwillingen. Unsere Untersuchungen berücksichtigen folgende Gesichtspunkte:

1. Es wurde nicht nach der Mortalität sondern durch Einbeziehung des Neugeborenen-Zustandsschemas unter dem empfindlicheren Aspekt der Morbidität beurteilt.

2. Da eine Sektio bei Zwillingsgeburten häufig aus kindlicher Indikation durchgefuhrt wird, fallen kurzes Zeitintervall $\mathrm{z}$ wischen der Entwicklung beider Kinder und höhere Gefährdung des zweiten Zwillings naturgemäß zusammen. Um solche Verfälschungen der Beziehung: Zeitintervall/Gefährdung des zweiten Zwillings auszuschließen, wurden nur vaginale Geburten berücksichtigt.

3. Durch Ziehen eines Gewichtslimites bei $2000 \mathrm{~g}$ wurde der Einfluß einer starken Untergewichtigkeit zweiter Zwillinge ausgeschlossen.

4. Die beim zweiten Zwilling häufig auftretenden Lageanomalien führen unabhängig vom Zeitintervall $\mathrm{zu}$ einer Verschlechterung der Bedingungen. Wir haben deshalb nur Geburten aus Schädellage berücksichtigt.

Beim Vergleich des Aziditätszustandes zeigte sich, daß sowohl die aktuellen pH-Werte im Nabelschnurarterienblut des 2. Zwillings (Fig. 1) mit zunehmendem Zeitintervall statistisch signifikant absinken. Dies trifft auch für die metabolische Azidität (pHqu40) zu. Auch die Differenz der aktuellen pH-Werte (Fig. 2) und der pHqu40Werte zwischen 1. und 2. Zwilling sinken mit Zunahme des Intervalles signifikant $a b$.

Aufgrund unserer Resultate ergibt sich für den Kliniker die Konsequenz, nach Geburt des ersten Zwillings - je nach klinischer Situation - möglichst bald auch die Geburt des 2 . Zwillings herbeizuführen.

Schlüsselworte: Azidose, Fet, Säure-Basen-Haushalt, Zustandsdiagnostik, Zwillingsgeburt

\section{Résumé}

Signification de l'intervalle de temps dans l'accouchement gémellaire

Afin de déterminer l'influence de l'intervalle de temps dans l'accouchement gémellaire, nous avons eu recours à des critères d'analyses plus stricts encore que ceux indiqués jusqu'à présent dans la littérature. Du 1.7.1970 au 31. 12. 1974, nous avons eu dans notre hôpital 35 accouchements gémellaires répondant aux conditions suivantes:

1. Naissance de jumeaux avec position du sommet.

2. Accouchement vaginal des deux jumeaux.

3. Poids à la naissance supérieur à $2000 \mathrm{~g}$.
L'étude a porté sur divers paramètres avec score clinique et d'acidité pour le seul deuxième jumeau ainsi que pour le rapport entre les deux jumeaux respectifs. Nos examens ont tenu compte des points suivants:

1. Le critère n'a pas été porté sur la mortalité, mais sur le facteur plus sensible de la morbidité dans l'état du nouveau-né.

2. Les accouchements gémellaires nécessitant souvent une section à cause de soufrance foetale, l'intervalle de temps entre la naissance des deux enfants et la mise en danger du $2 \grave{m}$ e jumeau sont naturellament liés; aussi 
avons-nous écarté cette complication pour ne prendre en considération que les accouchements vaginaux.

3. Tirant la limite inférieure à $2000 \mathrm{~g}$ pour le poids à la naissance, nous avons également exclu ainsi l'influence d'une insuffisance trop grande du poids du 2 ème jumeau.

4 Le 2ème jumeau se présentant souvent de façon anormale, les conditions de l'accouchement se trouvent donc compliquées indépendamment du facteur de l'intervalle de temps et c'est pourquoi nous n'avons tenu compte dans notre étude que des positions par le sommet.
Comparant l'état d'acidité, nous avons observé que lès valeurs actuelles du $\mathrm{pH}$ dans le sang de l'artère ombilicale du 2ème jumeau (Fig. 1) baissent de façon statistiquement significative à mesure que croît l'intervalle de temps. Ceci vaut également pour l'acidité métabolique (pHqu40). De même, la différence des valeurs actuelles du pH (Fig. 2) et des valeurs du pHqu40 entre le ler et le 2ème jumeau diminue de façon significative et parallèle à l'augmentation de l'intervalle.

A la suite de ces résultats, nous pensons que le clinicien doit faire succéder le plus rapidement possible et selon la situation clinique l'accouchement du 2ème jumeau à celui du ler.

Mots-clés: Accouchement gémellaire, acidose, équilibre acidobasique, état clinique, foetus.

Acknowledgement: We thank Mrs. K. Schmidt for statistical advices

\section{Bibliographie}

[1] BROWN, E. J., H. G. DIXON: Twin pregnancy. J. Obstet. Gynaec. Brit. Cwlth. 70 (1963) 251

[2] CAMILlERI, A. P.: In defence of the second twin. J. Obstet. Gynaec. Brit. Cwlth. 70 (1963) 258

[3] CORSTON, J. MCD.: Twin survival. Obstet. Gynec. 10 (1957) 181

[4] ECKERT, N., W. SPEN KE: Zwillingsschwangerschaft und perinatale Mortalität. Zbl. Gynäk. 94 (1972) 426

[5] KURZ, G. R., W. J. KEASING, J. B. LOFTUS: Twin pregnancy and delivery. Obstet. Gynec. 6 (1955) 370

[6] LANGER, H.: Perinatale Mortalität der Zwillingsgeburt. Zbl. Gynäk. 94 (1972) 1288

[7] LITTLE, W. A., E. A. FRIEDMAN: The twin delivery. Factors influencing second twin mortality. Obstet. Gynec. Surv. 13 (1958) 611

[8] MACDONALD, R. R.: Management of the second twin. Brit. med. J. 24 (1962) 518
[9] MUNNELL, E. W., H. C. TAYLOR: Complications and fetal mortality in 136 cases of multiple pregnancy. Amer. J. Obstet. Gynec. 52 (1946) 588

[10] RICHTER, J.: Mehrfache Geburt. Biologie und Pathologie des Weibes. 2. Auflage Bd. 7 (Berlin 1951) 717

[11] SALING, E.: Das Kind im Bereich der Geburtshilfe. Thieme, Stuttgart 1966

[12] SCHOLTES, G.: Zum Problem der Zwillingsschwangerschaft. Arch. Gynäk. 210 (1971) 188

[13] TOW, S. H.: Foetal wastage in twin pregnancy. J. Obstet. Gynec. Brit. Emp. 66 (1959) 444

[14] WADELL, K. E., J. S. HUNTER: Twin pregnancies. Amer. J. Obstet. Gynec. 80 (1960) 756

Received August 30, 1975. Accepted January 30, 1976.

Prof. Dr. E. Saling

Unit of Perinatal Medicine

Mariendorfer Weg 28-38

D-1000 Berlin 44/Germany

Dr. Wolfgang Müller-Holve

2. Universitätsfrauenklinik

Lindwurmstraße 2 a

D-8000 München 2 